\title{
THE STATUS OF EMPLOYED OF AN OFFENDER - CONDITION TO ATTRACT PATRIMONIAL LIABILITY
}

\author{
R.G. Florian
}

\section{Radu-Gheorghe Florian}

Faculty of Law and Economics, Law Department, AGORA University Oradea, *Correspondence: Radu-Gheorghe Florian, AGORA University Oradea, 8, Piața Tineretului St., Oradea, Romania e-mail: raduflorian@rdslink.ro

\section{Abstract:}

Financial liability of the employee is a variety of contractual liability arising from specific features of legal work. This study aims to analyze the concrete situations in which the patrimony can be held liable to the employee, given the diversity of employment situations in which an employee may be engaged.

Key-words: patrimonial liability, employee, labor relations, civil servant, military, administrator-employee.

\section{Introduction}

According to art. 254 paragraph 1 from Romanian Labor Code, employees have patrimonial liability, under the rules and principles of contractual liability for material damages caused to the employer by fault and in connection with their work.

By the definition of patrimonial liability from the content of art. 254 paragraph 1 of Labor Code, results that the essential precondition for economic liability is determined by the employee status of the offender that produces an injury to his employer.

Incidence of patrimonial liability does not raise special problems in the case of legal employment relationship, in its complete and typical form, generated by the individual labor contract. ${ }^{1}$

\section{Particular cases in which the employee is responsible}

Special situations arise in relation to liability of the guilty when the employer operates in the context of incomplete work relations (eg, personnel that, as provided by law, provide paid work time to other units, doctors from clinics, associated teachers, lecturers and consultants, external scientific staff, pupils and students during practice in production).

Generally accepted solution for these cases is the application of common law rules of liability for the damages caused by the persons mentioned.

From that rule exists, however, some exceptions; thus, there are certain categories of persons who, although not an employee, are under the patrimonial liability, however, under art. 254 paragraph 1 from Labor Code.

Such category of people is met if the damage was discovered after the termination of the individual employment contract, ie after termination of the status of employee within the injured unit. In such a case, the damage recovery is still in the patrimonial liability, regardless of whether the person has gone to another job or not. ${ }^{2}$

In the same category of exception from the status of employee of the individual responsible for patrimonial liability are also provisions of art. 3 Government Ordinance no.

\footnotetext{
${ }^{1}$ A. Țiclea - Tratat de dreptul muncii, $7^{\text {th }}$ Edition, Universul Juridic., Publishing House, 2014, p. 895. 


\section{R.G. Florian}

$121 / 1998$ that stipulates the military employees (and civilian employees of the military units) are financially responsible, no matter if, after the damage, they have or not military status (or an employee in that unit).

To be noted that in these cases operates material liability as provided by art. 102-110 of the old code, with the possibility of a decision of imputation if the employee does not assume responsibility through a written commitment to pay. This material liability applies even to civilian employees of public institutions referred to in art. 2 of the normative act, namely the Ministry of National Defense, Ministry of Interior, the Romanian Intelligence Service, Protection and Security Service, Foreign Intelligence Service, the Special Telecommunications Service and the Ministry of Justice.

The doctrine rightly observed that O.G. No. 121/1998 in relation to the new code is a special law and therefore applies the principle of "specialia generalibus derogant". ${ }^{3}$

The same is valid for the Law no. 384/2006 regarding the status of soldiers and sergeants volunteers, who in art. 7 paragraph 1 states that when they cause damages to the military unit are materially liable and not patrimonial, according to the new labor code.

Another exception is the category of the apprentices, which operate based on the contract of apprenticeship at the workplace, according to art. 208-210 of the Labor Code, and, of course, employees who have completed with employer contracts of qualification.

To be noted that also the employees temporarily transferred, under art. 45-47 of the Labor Code have a patrimonial liability to the host employer with which they are in fixed-term employment relationships, but not to the transferor employer of the individual employment contract, towards whom they are reliable under the Civil Code, as his employment contract with transferor employer is suspended or patrimonial liability occurs for the act that causes injury by the employee's fault and in connection with his work. Thus, since work is provided solely for the transferee employer, any damage to the transferor employer will be recoverable only under common law as for the work of an employee he is patrimonial liable only to the current employer, for which the work is done.

So, for engaging the employee's patrimonial liability is not enough for it to be an employee of the person who claims to have been caused damage, but it is also necessary that the effects of the individual employment contract not to be suspended when the employee committed the act of injury.

In return, in the case of delegation, the delegated employees are not liable towards the unit to which they were sent by their employer, because in such case there is not a legal work relationship between the delegated employees and the unit where they operate.

Compared to the injured, the guilty employee is civil-tort liable under the Civil Code. But prejudiced unit has also the option to solicit to the employer who ordered the delegation, compensation to cover damages under the liability of the principal for the acts of the servant provided by art. 1373 of Civil Code. It can turn at the same time against both (and the principal and the servant), which will be liable jointly and severally, according to art. 1382 of Civil Code. ${ }^{4}$

To be noted that, according to the system of liability created by the New Civil Code, the doctrine gave up the institution of the obligations in solidum, a French-inspired institution, because only this institution could explain the solidarity of one who responds for another's deed together with the direct author of the illegal act, in context in which the former art. 1003 of the old Civil Code only refers to the solidarity of those who are responsible for the prejudicial act. ${ }^{5}$

Or, in the current system, art. 1382 of Civil Code refers to the solidarity of those responsible for a prejudicial act, a form far superior and different from the old regulations contained in art. 1003 of the old Civil Code.

\footnotetext{
${ }^{3}$ I.T. Ştefănescu, Tratat teoretic şi practic de drept al muncii, 2nd Edition, "Universul Juridic" Publishing House, Bucharest, 2012, p. 778.

${ }^{4}$ L.Pop, I.F. Popa, S.I. Vidu, Tratat elementar de drept civil. Obligațiile, "Universul Juridic" Publishing House, Bucharest, 2012, p. 559.

${ }^{5}$ P. Tărchilă, Drept civil. Partea generală și Persoanele, Gutenberg Publishing House, Arad, 2008, p.67.
} 


\section{THE STATUS OF EMPLOYED OF AN OFFENDER - CONDITION TO ATTRACT PATRIMONIAL LIABILITY}

Nor the employee of the temporary employment is not patrimonial liable to user during his work. He will be directly civil-tort responsible for his illegal and culpable acts. Of course nothing prevents the user to formulate action for damages against temporary employment agent (the employer of the guilty employee), based on contract of availability which is a commercial contract, this being the case of contractual liability of temporary employment agent. In the case that the temporary employment agent pays the user in accordance with contractual liability, he will be directed to an action for recovery against his own person, in accordance with art. 254 of the Labor Code ${ }^{3}$.

The literature stated that the logical and unitary interpretation of the law no. 31/1990, the liability of directors, auditors and liquidators of companies, even if they are employees of these companies, as well as executives, is a civil liability - in the broad sense of the term. This would result unequivocal from provisions of art. 72 that states that "the obligations and responsibilities of directors are governed by the provisions referring to the mandate and those specially provided by this law"); of art. 166 paragraph 1 that states "the extent and effects of auditors' liability are determined by the rules of mandate"; of art. 253 paragraph 2 under which "liquidators have the same liability as directors", as well as art. 152 paragraph 3 that states that the executives are accountable to society, the same as administrators. ${ }^{6}$

I do not agree with such a view, because the rules of the mandate referred to in law no. 31/1990 do not automatically exclude patrimonial liability.

Thus, the assessment of guilt, determination of injury, of the illegality of the act of the administrator, auditor and liquidator who also fulfills the status of employee will be appreciated, indeed, by the rules of the mandate set out in the Civil Code, but the legal status of establishment of patrimonial liability as well prejudice recovery arrangements will be governed exclusively by the rules of labor law, the rules contained in art. 253-259 of Labor Code.

Only in this way can be appreciated the concern of the legislature to make express reference to rules regarding the mandate in assessing liability of the administrator, a natural concern as long as the duties of the administrator, auditor and liquidator are expressly stipulated by mandatory rules contained in special laws.

In the academic literature was stated that the civil liability of directors is a civil one ${ }^{7}$, delictual against third parties (eg in case of insolvency proceedings, when the administrator may be required to pay the liabilities of the company, in the cases and according to art. 135 of Law no. 85 / 2006) and contractual towards the company grafted onto the existing mandate contract between the company and the administrator, based on art. 72 of law no. $31 / 1990 .{ }^{8}$

All of these assumptions do not cover the situation where the manager acts as administrator under an individual contract of employment with the company. Therefore, we consider that nothing precludes that, in the case of the assessment of conditions of liability of the administrator, to consider the rules of the mandate provided by art. 2025-2029 of Civil Code and Law no. 31/1990, and regarding the establishing the liability, injury recovery to be according to the provisions of art. 253-259 of Labor Code.

As regarding public servants, art. 84 of Law no. 188/1999, states that civil servants' liability is a civil one and not patrimonial (within the meaning of the Labor Code). It occurs to:

- prejudices produced with culpability to the patrimony of public authority or institution in which he works;

- failure to return within the legal term of the amounts they were given unduly;

- damages paid by the public authority or institution as principal, to third parties, on the basis of final and irrevocable court decisions.

\footnotetext{
${ }^{6}$ Ş. Beligrădeanu - Derogări de la dreptul comun al muncii cuprinse în Legea nr. 31/1990 privind societăţile comerciale” published in „Dreptul” revue no. 9-12/1990, pp. 32-37.

7 St. Cărpenaru, Tratat de drept comercial român, $3^{\text {rd }}$, "Universul juridic", Publishing House, 2012, p. 223; St.D.Cărpenaru, S.David, C.Predoiu, Gh.Piperea, Legea soceităţilor, Comentariu pe articole, C.H. Beck Publishing House, 2014, p. 256.

${ }^{8}$ P. Tărchilă, I. Micle, Drept comercial, ”Orizonturi Universitare” Publishing House, Timișoara, 2015, p. 320.
} 
There will not be patrimonial liability, in the accordance with the labor code, for the person providing work to another person or entity as a student in a school of arts and crafts or professional student during practice, or as a volunteer. In these cases, if an injury occurs by committing an act in relation to his work, the latter will respond only under the provisions of civil law (tort or contractual if there are civil contracts in this aspect) without the incident of patrimonial liability. ${ }^{9}$

The same situation is encountered in the case of forestry personnel employed within public institutions and authorities, with powers in the field of forestry, who will respond according to the rules of civil liability of public servants and not based on patrimonial liability as was natural. Thus, according to art. 58 paragraph 1 of GEO 59/2000 "to forestry personnel apply the provisions of Law no. 188/1999 regarding the status of civil servants, to the extent that this emergency ordinance otherwise provides", motive for which civil liability of forestry personnel, whether public servant or employee, shall be determined according to the procedure prescribed by law no. $188 / 1999$.

Currently, the Supreme Court debated the problem of material competence of courts in the matter of patrimonial liability for forestry staff who has the status of an employee, establishing by decision no. $3 / 2014$ that in the interpretation and application of art. 6 paragraph (1) of Government Emergency Ordinance no. 85/2006 regarding the procedures for assessment of damages produced to vegetation from forests and outside, approved with amendments and completions by Law no. 84/2007, in conjunction with art. 254 and art. 266 of Law no. 53/2003 Romanian Labor Code, republished, with subsequent amendments, in relation to Art. 58 paragraph (1) of Government Emergency Ordinance no. 59/2000 regarding the status of forestry staff, approved with amendments and completions by Law no. 427/2001, amended, actions in patrimonial liability brought against the staff responsible for forest security for the damages produced on wood surfaces they are supposed to watch, in terms of art. 1 letter the Government Emergency Ordinance no. 85/2006, are of material jurisdiction of the courts of labor disputes.

Consequently, the liability for damage caused to forest staff who is an employee shall not be trained in accordance with the rules of contractual liability of public officials, the incident being the norms of patrimonial liability set out in art. 253-259 of Labor Code.

\section{Conclusions}

The employee responds in patrimonial principle, but there are special rules or doctrinal interpretations that establish another form of liability for the employee for the damages produced to his employer.

\section{Bibliography}

1. P. Tărchilă, I. Micle, Drept comercial, ”Orizonturi Universitare” Publishing House, Timişoara, 2015;

2. A. Ticlea - Tratat de dreptul muncii, $7^{\text {th }}$ Edition, Universul Juridic., Publishing House, 2014;

3. St. Cărpenaru, Tratat de drept comercial român, $3^{\text {rd }}$, "Universul juridic", Publishing House, 2012, p. 223; St.D.Cărpenaru, S.David, C.Predoiu, Gh.Piperea, Legea soceităţilor, Comentariu pe articole, C.H. Beck Publishing House, 2014

4. I.T. Ştefănescu, Tratat teoretic şi practic de drept al muncii, $2^{\text {nd }}$ Edition, "Universul Juridic" Publishing House, Bucharest, 2012;

5. L.Pop, I.F. Popa, S.I. Vidu, Tratat elementar de drept civil. Obligațiile, "Universul Juridic" Publishing House, Bucharest, 2012;

6. P. Tărchilă, Drept civil. Partea generală și Persoanele, Gutenberg Publishing House, Arad, 2008;

7. Ş. Beligrădeanu - Derogări de la dreptul comun al muncii cuprinse în Legea nr. 31/1990 privind societăţile comerciale” published in „Dreptul” revue no. 9-12/1990.

${ }^{9}$ I.T. Ștefănescu - op.cit., p. 779. 